\title{
Politics and theory of global governance
}

\author{
Orfeo Fioretos $^{1 \star}$ (D) and Jonas Tallberg ${ }^{2}$ (D) \\ ${ }^{1}$ Department of Political Science, Temple University, Philadelphia, PA, USA and ${ }^{2}$ Department of Political \\ Science, Stockholm University, Stockholm, Sweden \\ ${ }^{*}$ Corresponding author. E-mail: fioretos@temple.edu
}

(Received 9 June 2020; accepted 26 June 2020; first published online 28 December 2020)

\begin{abstract}
At a point when global governance appears to be at a crossroad, caught between globalizing and national populist forces, International Relations theorists are deeply immersed in debating what brought the world to this point. This contribution enlists Michael Zürn's $A$ Theory of Global Governance (2018) to explore the state of global governance theory through a focus on three substantive themes: authority, legitimacy, and contestation in global governance. It identifies the current state of theorizing on each theme, situates Zürn's claims within these literatures, and previews counterpoints from a variety of theoretical perspectives.
\end{abstract}

Keywords: global governance; international organizations; authority; contestation; legitimacy; reflexivity

Global governance may be at a crossroad. From one perspective it is clear that there has never been a time when relations between states, international organizations (IOs), and global civil society have been more densely institutionalized. Today's global governance is unprecedented in its scope, affecting virtually every area of international and transnational politics through a variety of institutions that appear to have become more plentiful and powerful with time. From this perspective, global governance institutions are path-dependent structures that contribute to a relatively stable, if somewhat inchoate, system of global governance. But from a different perspective, global governance institutions are facing backlash and may unravel. They are under siege and are vulnerable, with a growing number of governments and political movements contesting the legitimacy of these institutions. Whether in the context of the United Nations, the World Trade Organization, the International Criminal Court, or any other of a large number of institutions that populate the global system of governance, politicization has reached a point not seen since the 1930s. Once again populism is capturing political imaginations around the world, and once again global governance institutions are fiercely contested. 
The future will reveal how global governance evolves from this crossroad. In the meantime, International Relations (IR) theorists are deeply immersed in debating what brought global governance to this point. They inquire into the origins and durability of global governance institutions and the extent to which these possess political authority. They explore how traditional IOs have been complemented, and sometimes challenged, by a proliferation of newer forms of global governance institutions, from transgovernmental networks to transnational hybrid institutions and private arrangements. They study the sources and limits of legitimacy in global governance institutions. And they investigate what the past and present reveal about the effects of political contestation for the state of global governance.

This symposium uses Michael Zürn's A Theory of Global Governance as a springboard to explore these themes and, more generally, the state of global governance theory. ${ }^{1} A$ Theory entails an ambitious argument about the state of global governance, including the claim that global governance itself represents a system of politics that renders the contemporary international system qualitatively different from past ones. Zürn defines global governance as 'the exercise of authority across national borders as well as consented norms and rules beyond the nation state', and argues that the contemporary system is characterized by both significantly greater levels of global authority and contestation of that authority. ${ }^{2}$ He analyzes a cycle from rising authority beyond the (nation-)state through the $20^{\text {th }}$ century, to multiple legitimation problems toward the century's end, to the politicization and contestation triggered by such problems in the contemporary period. For Zürn, theorizing the current crossroad in global governance requires a commitment to capturing the dynamic, at times dialectical, and often fraught relationship between forces constructing and contesting institutionalized authority beyond the state.

Zürn confronts analytical building blocks that have long informed IR theory and global governance studies. Like many scholars of international cooperation, he distances himself from realist traditions that dispute the role of global governance institutions. He also goes much beyond realism's traditional focus on great powers to consider the interaction among states, IOs, and societal actors. Zürn works within a large institutionalist tradition that studies the effects of formal and informal rules in shaping global politics. For him, global governance institutions are many and diverse, stretching from large formal intergovernmental organizations like the United Nations to private organizations like Standard and Poor's that exercise authority beyond the nation state. ${ }^{3}$ The emphases on contestation, actor pluralization, and an encompassing understanding of global governance institutions means that Zürn departs in some important ways from predominant understandings within the institutionalist IR tradition. For several decades, that tradition has portrayed states as embracing institutions as means to solve collective action problems. ${ }^{4}$ By contrast, Zürn sees institutions as inherently contestable, and more so as their authority grows and legitimacy gaps emerge. In one forceful comment he marks this departure from standard institutional theory and declares that he

\footnotetext{
${ }^{1}$ Zürn 2018.

${ }^{2}$ Zürn 2018, 4-5.

${ }^{3}$ Zürn 2018, 4.

${ }^{4}$ Keohane 1984; Koremenos 2016.
} 
'aims to demolish the seemingly unbreakable elective affinity between institutionalism and a cooperative reading of world politics' ${ }^{5}$

The emphasis on the contestable nature of global governance institutions is not new to the field; for instance, it features in an extensive literature on global civil society movements. ${ }^{6}$ Zürn injects new energy to the issue with important implications for theorizing the ebbs and flows of contestation, as well as their consequences for the evolution of global governance over time. Zürn recognizes that governance arrangements often reach crossroads. A central theme of $A$ Theory is that many institutions considered legitimate in the recent past are now under siege and that the sources of contestation cannot be narrowly attributed to shifting balances of power or a lack of institutional devices. Rather, contestation happens because global governance institutions represent values and practices that have acquired an authoritative quality that is not accepted as legitimate by select transnational and national actors. The more important global governance institutions have become for some actors, the more hotly contested they are by others.

Zürn is interested in the causal mechanisms that serve to legitimate and contest the authority of global governance institutions. Working with historical institutional IR theory, he suggests that global governance institutions are shaped by a variety of temporal mechanisms, including positive and negative feedback effects, path dependence, and reactive sequences. ${ }^{7}$ More forcefully than extant research in that tradition, Zürn maintains that the analytical focus in global governance studies should be on the internal dynamics of a system. In $A$ Theory, internal dynamics set causal mechanisms in motion that over time produce, reinforce, or undermine global authority. From this perspective, global politics is embedded in a normative and institutional structure that contains hierarchies and power inequalities and thus endogenously produces contestation, resistance, and distributional struggles. ${ }^{8}$ In theorizing these endogenous logics, Zürn moves beyond consequentialist logics that inform cooperative readings of institutions. He also steps away from the emphasis on logics of appropriateness that characterizes some constructivist understandings of global institutions. He instead develops a theory of reflexive authority in which logics of deference play a central role in explaining why states accept global governance institutions as legitimate. From there he moves to explore how historical patterns of consent and contestation have contributed to a landscape of 'loosely coupled spheres of global authority'.

The starting point in Zürn's model is the rise of international authority, which is a function of global governance institutions possessing growing levels of political and epistemic authority. ${ }^{9}$ This rise requires legitimation in the form of justifications. Yet, such justifications may run into problems, including an over-reliance on technocratic narratives and an exercise of authority that is biased in favor of the most powerful states. For Zürn, these legitimation problems provoke contestation from state and societal actors, in the shape of protests and demands for

\footnotetext{
${ }^{5}$ Zürn 2018, 3.

${ }^{6}$ Della Porta and Tarrow 2005; Scholte 2011.

${ }^{7}$ Fioretos 2011; Rixen et al. 2016.

${ }^{8}$ Zürn 2018, 3.

${ }^{9}$ Zürn 2018, ch. 4.
} 
change. The responses to these challenges may lead to adjustments in existing institutions, the creation of alternative institutions by rising and established powers, or institutional gridlock. Ultimately, how states and institutions deal with these challenges will determine whether global governance goes down a path of deepening in order to regain legitimacy, or decline as arrangements are undermined without corresponding efforts at replacement.

Contributors to this symposium praise $A$ Theory for its rich, nuanced, and novel understanding of global governance, calling it among other things 'a major theoretical statement', and an 'original, bold, and compelling argument'. But, Zürn's interlocutors also raise difficult questions that are informed by different theoretical traditions. Inevitably for a book with such great ambition, contributors challenge some core arguments of the book and identify select blind spots. All agree, however, that $A$ Theory offers a particularly fitting springboard for theorizing and discussing the contemporary state of global governance.

We organize the debate over Zürn's A Theory around the book's core themes: authority, legitimacy, and contestation in global governance. These themes are central also to IR scholarship on global governance generally, as represented by the contributions to the symposium. We identify the current state of theorizing on each theme, situate Zürn's claims within these literatures, and preview the arguments of the symposium contributions.

\section{Authority in global governance}

Few concepts occupy a more central position in the social sciences disciplines than authority. It is broadly understood to mean a situation in which members of a community voluntarily accept a set of rules and norms. Max Weber argued that authority was a special case of power. ${ }^{10}$ The German sociologist has been the central reference point for how authority has been understood for generations of social scientists. Weber emphasized voluntary consent or subordination as a defining element of authority, and embraced a hierarchical understanding of how it expresses itself within a system of governance. Whether in what Weber called its traditional, charismatic, or bureaucratic forms, authority is understood as a topdown relationship with members of the polity accepting as legitimate the power of their superiors. But as a large IR literature notes, exactly who possesses authority in the international system is far from clear. ${ }^{11}$

In the absence of a world state, IR scholars have long puzzled over what gives global institutions authority. IR's authority puzzle is different from the domestic and local contexts explored by Weber, where state bureaucracies possess the infrastructure to elicit consent from the polity. By contrast, in the case of global governance it is not clear that organizations and institutions possess meaningful authority over states. How can one say that IOs have power over states when the former is funded by the latter, when the latter faces few sanctions from non-compliance with international commitments, and when states selectively reject established notions of obligation and willingly withdraw from treaties and organizations?

\footnotetext{
${ }^{10}$ Weber 1922/1978.

${ }^{11}$ E.g. Barnett and Finnemore 2004; Avant et al. 2010; Lake 2010; Krisch 2017.
} 
Contributions to IR theory have tended to solve the authority puzzle in one of two ways: either with reference to the use of contracts or by looking at processes of socialization. The former approach, described by Zürn as a model of contracted authority, conceives of authority as the outcome of autonomous actors (principally states) signing treaties and establishing organizations which they obey because of the benefits they associate with them. ${ }^{12}$ The latter approach solves the authority puzzle by conceiving of authority as a relationship in which actors are socialized into accepting prescribed global rules and norms. These models of inscribed authority are found in constructivist IR theory and detail how states and other international actors learn to observe common understandings. ${ }^{13}$ Zürn proposes a model of reflexive authority. While the contracted authority model stresses rationalist logics of consequence and inscribed authority models emphasize logics of appropriateness, Zürn suggests that a better solution to the authority puzzles can be found by exploring logics of deference.

Zürn's theory of reflexive authority conceives of states and international actors as entities that accept global rules and norms because they recognize their own limitations to autonomously understand or solve global problem. States and other actors therefore reflexively defer to the rules and norms that are associated with global organizations and practices. Zürn details in both quantitative and qualitative terms that global governance institutions have with time acquired political and epistemic foundations. Political bargains between states that are codified in binding decisions and prescriptive norms are a big part of the story. These have grown in scope, especially after 1945 and with greater reach yet after 1989. With colleagues, Zürn constructed an international authority score to measure the evolution of political authority that he uses to document its rapid ascent over time and its growing policy scope. ${ }^{14}$ In $A$ Theory, he declares that the 'enormous rise' in international authority since 1990 represents 'system change'.

In theorizing this system change in global governance, Zürn takes particular interest in 'epistemic authority'. Epistemic authority refers to expert knowledge and moral integrity that are 'objectivized' by a panoply of global institutions. ${ }^{15}$ From the United Nations Framework Convention on Climate Change, the Sustainable Development Goals, and trade treaties to the laws governing war, human rights, and the digital domain, there are now authoritative understandings and practices of how to address transnational problems. Zürn documents a rise in technocratic and fairness narratives in public debates that far outstrip discussions of participation in policy-making. ${ }^{16} \mathrm{He}$ contends that such authority is a product of the widespread - and reflexive - acceptance that global institutions offer solutions to how common problems are best solved. States and other actors accept the epistemic authority of these institutions and thus give them a taken for granted quality that represents global authority - or, as Weber may have put it, a special case of global power.

\footnotetext{
${ }^{12}$ E.g. Keohane 1984; Koremenos et al. 2001; Lake 2010.

${ }^{13}$ E.g. Wendt 1992; Hurd 2007; Pouliot 2016.

${ }^{14}$ Zürn 2018, 111, 126-27.

${ }^{15}$ Zürn 2018, 52-53.

${ }^{16}$ Zürn 2018, 166-67.
} 
Inspired by Zürn's account, contributors to this symposium raise three sets of questions concerning the authority of global governance institutions. First, they inquire about the reference points that feature in Zürn's study. Specifically, they wonder whether Zürn's understanding of global governance may be drawing too heavily on the post-Cold War era and the European Union (EU) example. The extent of authority enjoyed by IOs varies considerably and the EU is at one extreme. ${ }^{17}$ Robert Keohane asks pointedly and Jan Aart Scholte more indirectly whether a similar book would have been written had a different reference point been used to understand politics beyond the nation-state. ${ }^{18}$ In a similar vein, Nicole Deitelhoff and Christopher Daase note that the darker sides of global governance are not highlighted, while Michael Barnett raises questions about the optimistic tones of Zürn's historiography of global governance. ${ }^{19}$ Much of post-1945 global governance, they note, was associated with deep inequalities and coercive qualities, even when it has appeared to have featured high levels of cooperation.

Second, contributors agree that Zürn's reflexive theory of governance marks an important addition to an expanding literature on global governance as an exercise of authority. To Zürn, global governance institutions have authority when state and non-state actors recognize, in principle or in practice, that their choices are formed at least partially in deference to global norms and rules. Judith Kelley and Beth Simmons find great merit in this perspective and note that as the legitimacy of some global economic organizations like the World Bank came into question, they turned to performance assessments and ranking systems to enhance their authority and minimize further contestation. ${ }^{20}$ Meanwhile, Vincent Pouliot wonders if Zürn's theory of reflexive authority may be overstating the level of global epistemic authority. He points instead to diplomatic practices that predate 1945 as mechanisms that propel a mixture of authority constructs, and seeks answers to when global technocratic expertise really trumps national authorities. ${ }^{21}$

Finally, a third theme raised by contributors concerns the tendency to equate authority in global governance with intergovernmental organizations. What form global governance institutions take is not a given. It varies greatly. ${ }^{22}$ Global governance institutions range from intergovernmental organizations and transgovernmental networks to transnational hybrid and private arrangements. To varying degrees, these institutional forms involve governance not only through hierarchies, but also the use of novel market-based solutions and networks to address global and transnational problems. ${ }^{23}$ Going one step further, Anna Leander suggests that the central actors and processes in global cybersecurity governance are altogether different from those in $A$ Theory. From this perspective, global governance appears more disordered and discontinuous than a focus on authoritative global governance institutions would suggest. ${ }^{24}$

\footnotetext{
${ }^{17}$ E.g. Hooghe et al. 2017.

${ }^{18}$ Keohane 2020; Scholte 2020.

${ }^{19}$ Deitelhoff and Daase 2020; Barnett 2020.

${ }^{20}$ Kelley and Simmons 2020.

${ }^{21}$ Pouliot 2020.

${ }^{22}$ Barnett 2020; Scholte 2020.

${ }^{23}$ Kelley and Simmons 2015; Barnett et al. 2021.

${ }^{24}$ Leander 2020.
} 


\section{Legitimacy in global governance}

While global governance institutions have been conferred growing authority in recent decades, the capacity of these institutions to deliver on their promise is conditioned on their legitimacy in the eyes of governments and citizens. When audiences view an institution as legitimate, they have confidence in its rule and are more likely to endorse and comply with its policies. Yet, despite the importance of legitimacy for global governance, we still have little systematic knowledge about its sources, processes, and consequences. ${ }^{25}$

Expressed in terms of a common distinction, the principal interest of this symposium is legitimacy in the sociological sense - actors' perception of an institution's authority as appropriately exercised - rather than legitimacy in the normative sense - an institution's exercise of authority as rightful and worthy of recognition based on its conformance to principles such as justice, public interest, and democracy. ${ }^{26}$ In this conceptualization, legitimacy is distinct from authority. While authority, as discussed above, refers to the recognition that an institution has the right to make decisions and interpretations within a particular area, legitimacy refers to the perception that these rights are appropriately exercised. ${ }^{27}$ Legitimacy is thus a relational property, determined by the beliefs and perceptions of audiences about the exercise of authority. ${ }^{28}$

Several classical approaches in IR have touched on the topic of legitimacy. Realist scholarship usually sees legitimacy as a tool of power that states exploit to advance their interests, but that does not constrain their actions. ${ }^{29}$ In contrast, liberal institutionalists have viewed legitimacy more positively, highlighting its functional usefulness to the collective of states. ${ }^{30}$ Constructivists have devoted the most sustained attention to legitimacy, exploring how legitimate international law can exercise a compliance pull, how states use and contest the legitimacy of global institutions, and how these institutions embody legitimate authority. ${ }^{31}$ More recently, legitimacy has emerged as a topic in two strands of middle-range theorizing. A growing number of studies map and explain the legitimacy of global governance institutions through public and elite opinion. ${ }^{32}$ Other studies address how global governance institutions are legitimized and delegitimized through practices aimed at boosting or undermining their legitimacy. ${ }^{33}$

A Theory makes several claims about legitimacy and legitimation. It joins other recent contributions in stipulating that legitimacy in global governance is intimately tied to the authority of these institutions. ${ }^{34}$ Legitimacy only becomes an issue once an institution possesses authority. In the absence of authority, there would be no legitimacy problem. Zürn refers to this connection as the 'authority-legitimacy

\footnotetext{
${ }^{25}$ Tallberg et al. 2018.

${ }^{26}$ Buchanan and Keohane 2006.

${ }^{27}$ Tallberg and Zürn 2019, 6.

${ }^{28}$ Hurd 2007, 7; Reus-Smit 2007, 44.

${ }^{29}$ Carr 1946.

${ }^{30}$ Keohane 2006.

${ }^{31}$ Franck 1990; Hurd 2007; Barnett and Finnemore 2004.

${ }^{32}$ Dellmuth and Tallberg 2015.

${ }^{33}$ Zaum 2013.

${ }^{34}$ E.g. Bernstein and Pauly 2007; Hurd 2007.
} 
link'. The implication is clear: if global governance institutions are conferred ever increasing authority, the risk of legitimacy deficits expands as well, unless these institutions are effectively legitimated through reference to common norms. In this respect, global governance institutions face the same requirements of legitimation through narratives as do states. ${ }^{35}$ This takes us to the second part of Zürn's argument, namely the legitimation narratives that may be used to justify the authority of global governance institutions. While political authority in the domestic setting historically has been legitimated through a broad range of narratives, the options are more limited in global governance. Zürn argues that global institutions effectively only have recourse to technocratic and legal narratives, justifying their authority with reference to expertise and impartiality. Yet, these legitimation narratives are insufficient to properly justify the extensive authority of global governance institutions today. The results, Zürn notes, are frequent legitimation problems and legitimacy deficits.

Inspired by Zürn's account, the contributions to the symposium engage with two themes related to legitimacy in global governance. To begin, they ask who the audiences are whose legitimacy beliefs count. Legitimate global governance in the eyes of whom? For Barnett, Zürn focuses too narrowly on the legitimacy perceptions of state and societal actors in the Western powers. ${ }^{36}$ Assessing the legitimacy of global governance requires a broader take on relevant audiences that encompasses those excluded from, or marginalized within, these institutions. For instance, how legitimate were the institutions of the postwar era in the eyes of the newly decolonized states, which had no role in creating them and were not allowed to sit at the table? While $A$ Theory partly addresses this gap in its attention to present-day challenges from rising powers, the question of relevant audiences continues to loom large.

A second major theme concerns the sources of legitimacy. In line with other recent scholarship, Zürn distinguishes between procedure and performance as two complementary institutional sources of legitimacy, together offering a basis for a broad range of legitimation narratives in global governance. Yet, this focus comes with theoretical limitations. Barnett suggests that Zürn's account may attach undue weight to legitimation through procedural qualities (e.g. expertise, efficiency, legality, and impartiality), when global governance institutions in reality may be most prominently judged and justified based on performance qualities, such as responsiveness and effectiveness. Scholte takes this critique a step further when arguing that institutional qualities only constitute one possible source of legitimacy for global governance institutions. ${ }^{37}$ Sources which may be equally important, but so far have received limited attention, include structural features, such as hegemonic relationships, capitalist ideas, and discursive structures, as well as individual conditions, such as interests, identities, and personal predispositions. From this perspective, exploring the multiple sources of legitimacy, and their interactions, is the next research frontier.

\footnotetext{
${ }^{35}$ Cf. Krebs 2015, Steffek 2003.

${ }^{36}$ Barnett 2020.

${ }^{37}$ Scholte 2020.
} 


\section{Contesting global governance}

While global governance always has involved an element of resistance and opposition from state and societal actors dissatisfied with the prevailing institutional order, the intensity and quality of this contestation appears to have changed in recent decades. In the famous words of Leon Lindberg and Stuart Scheingold, global governance can be said to have benefited from a state of 'permissive consensus', where populations have enjoyed the fruits of cooperation and supported its broad goals, while taking little concrete interest in the process through which these benefits were produced. ${ }^{38}$ According to Zürn, this state came to an end around 1990, giving way to growing awareness, politicization, and contestation of IOs, eventually producing a new state of 'constraining dissensus'. ${ }^{39}$

Contestation of global governance comes in multiple forms and shapes. Rising powers express dissatisfaction with their voice in the principal IOs of the liberal international order. National governments criticize global governance institutions to force policy change, deflect blame, or mobilize domestic supporters. Populist parties on the right and the left attack global governance institutions for undermining national sovereignty and producing inequality. Non-governmental organizations (NGOs) challenge global governance institutions for insufficiently ambitious policies and undemocratic decision-making procedures. Citizens protest on the streets or in referenda against global governance institutions often perceived as too distant from the realities of their everyday lives.

Recent years have witnessed growing efforts among IR scholars to grapple with the nature of contestation in global governance. Usually, these contributions have sought to map and explain particular types of contestation, while their consequences have received less sustained attention. Reflecting their grounding in different literatures, these works have also tended to focus on contestation by separate actor categories, rather than analyzing contestation as a phenomenon involving a multitude of actors. Growing out of social movement research, one set of contributions explores opposition by NGOs against global governance institutions. ${ }^{40}$ Another strand looks at the power of the corporate sector to shape global governance. ${ }^{41} \mathrm{~A}$ third set of studies examine states' contestation of global governance institutions as a means to further their objectives in world politics. ${ }^{42}$ More recently, scholars have sought to better understand what drives populist parties to challenge particular organizations. ${ }^{43}$

A Theory locates the sources of contestation in the legitimacy deficits that have arisen in the wake of growing international authority. Consistent with Zürn's endogenous account of change, it is the success of global governance institutions in accumulating authority that has brought about these challenges: 'Growing resistance to inter- and transnational institutions is to be expected if they exercise authority but cannot build on sufficient stocks of legitimacy. The authority-

\footnotetext{
${ }^{38}$ Lindberg and Scheingold 1970.

${ }^{39}$ See also Hooghe and Marks 2009; Zürn et al. 2012.

${ }^{40}$ E.g. O’Brien et al. 2000; Della Porta and Tarrow 2005.

${ }^{41}$ E.g. Leander 2005; Young 2012.

${ }^{42}$ E.g. Morse and Keohane 2014; Daase and Deitelhoff 2015.

${ }^{43}$ E.g., Hooghe et al. 2019.
} 
legitimacy link thus explains the dynamics of societal and state contestation in the global governance system'. ${ }^{44}$ But the story does not end there. Moving from origins to consequences, Zürn suggests that contestation may produce either a deepening or a decline in global governance. When IOs respond to challenges by adjusting their procedures and developing their policies, a stronger system of global governance may result. But contestation may also bring about gridlock and demise, as when incumbent powers and IOs resist calls for reform from rising powers and civil society. Both options are on the table. The likely outcome is not an either-or scenario, according to Zürn, but an as-well-as scenario where deepening and decline in global governance take place in parallel.

Contributors to the symposium see many merits in Zürn's theory of contestation, but also offer important alternative messages. Keohane and Barnett submit that Zürn's account neglects perhaps the most prominent challenge of global governance institutions today, namely contestation by populist governments and parties, as illustrated by recent developments in Brazil, Hungary, Italy, the UK, and the USA. According to Keohane, contestation nowadays goes well beyond criticism from rising powers and NGOs that accept the basic principles of the global governance system, but seek changes to its procedures and consequences. Opposition comes now also from regimes and movements that reject the very principles of global governance. ${ }^{45}$ In a similar vein, Barnett suggests that a renewal of local and national identities may be the logical counter-reaction to a global governance system with cosmopolitan intent: 'For many, the revolt against global governance is not simply a return of nationalism in its most pejorative meaning but an attempt to maintain a sense of self. ${ }^{46}$ Deitelhoff and Daase take this logic a step further and suggest that resistance goes hand in hand with rule. Since rule in global governance seldom is observable in itself, it is through resistance by state and societal actors that international authority is manifested.

A second message pertains to the consequences of contestation in global governance. Kelley and Simmons, as well as Barnett, suggest that one of the principal implications of authoritative IOs being increasingly contested is a shift in governance forms. Rather than a deepening or decline of international cooperation as we know it, the effect of contestation is the emergence and growth of alternative governance forms that fly beneath the radar of resistance and opposition. Kelley and Simmons specifically highlight the growth of global performance indicators (GPIs), such as ratings and rankings, which present a convenient governance instrument for IOs wishing to be effective without being overly directive. GPIs enable IOs such as the World Bank to avoid igniting contestation by incentivizing change through comparison and competition, rather than hard commanding rules. Barnett shares this analysis, and expands it further to encompass also other forms of market- and network-based forms of global governance that are emerging as alternatives to hierarchy-based IOs.

\footnotetext{
${ }^{44}$ Zürn 2018, 11.

${ }^{45}$ Keohane 2020.

${ }^{46}$ Barnett 2020, 141.
} 


\section{Conclusion}

As global governance institutions appear increasingly contested by state and nonstate actors alike, the importance of understanding their nature and impact is becoming ever more urgent. This symposium is an early down-payment on such efforts. It makes three contributions to current theorizing on global governance. First, it considers how further attention to authority, legitimacy, and contestation will help future scholarship better account for changes and innovations in contemporary global governance. Second, by engaging Zürn's theory of global governance, the symposium highlights strengths and shortcomings of a variety of theoretical positions and identifies ways in which the latter can be overcome through new theoretical partnerships. Finally, the symposium entails reflections on methods for capturing authority in global governance, deeper structural foundations in global governance, and the relationship between positive and normative theorizing on global governance. In this way, contributors to the symposium detail new lines of inquiry that promise to enhance understandings of global governance at and beyond its current crossroad.

Acknowledgement. The authors thank the contributors to this symposium, especially Michael Zürn, for their productive engagement, the journal's anonymous reviewers for constructive feedback, and the former and current editorial teams as well as Dominic Byatt for their collegial cheer and support of the project. Jonas Tallberg would like to thank Riksbankens Jubileumsfond (Grant M15-0048:1) for generous research funding.

\section{References}

Avant, Deborah D., Martha Finnemore, and Susan K. Sell, eds. 2010. Who Governs the Globe? Cambridge and New York: Cambridge University Press.

Barnett, Michael. 2020. “Change In or Of Global Governance?” International Theory 13 (1): 131-43.

Barnett, Michael, Jon Pevehouse, and Kal Raustiala. 2021. "Introduction," in Michael Barnett, Jon Pevehouse, and Kal Raustiala, eds., Global Governance in a World of Change. New York: Cambridge University Press.

Barnett, Michael, and Martha Finnemore. 2004. Rules for the World: International Organizations in Global Politics. Ithaca: Cornell University Press.

Bernstein, Steven, and Louis Pauly, eds. 2007. Global Liberalism and Political Order: Toward a New Grand Compromise. Albany: State University of New York Press.

Buchanan, Allan, and Robert O. Keohane. 2006. "The Legitimacy of Global Governance Institutions." Ethics \& International Affairs 20 (4): 405-37.

Carr, Edward Hallett. 1946. The Twenty Years' Crisis 1919-1939. 2nd edition. London: Macmillan.

Daase, Christopher, and Nicole Deitelhoff. 2015. "Jenseits der Anarchie: Widerstand und Herrschaft im Internationalen System.” PVS Politische Vierteljahresschrift 56 (2): 299-318.

Deitelhoff, Nicole, and Christopher Daase. 2020. "Rule and Resistance in Global Governance." International Theory 13 (1): 122-30.

Della Porta, Donatella and Sidney J. Tarrow, eds. 2005. Transnational Protest and Global Activism. Lanham, MD: Rowman \& Littlefield.

Dellmuth, Lisa M., and Jonas Tallberg. 2015. “The Social Legitimacy of International Organisations: Interest Representation, Institutional Performance, and Confidence Extrapolation in the United Nations." Review of International Studies, 41 (3): 451-75.

Fioretos, Orfeo. 2011. "Historical Institutionalism in International Relations." International Organization 65 (2): 367-99.

Franck, Thomas M. 1990. The Power of Legitimacy among Nations. Oxford: Oxford University Press. 
Hooghe, Liesbet, and Gary Marks. 2009. "A Postfunctionalist Theory of European Integration: From Permissive Consensus to Constraining Dissensus." British Journal of Political Science 39 (1): 1-23.

Hooghe, Liesbet, Gary Marks, Tobias Lenz, Jeanine Bezuijen, Besir Ceka, and Svet Derderyan. 2017. Measuring International Authority: A Postfunctionalist Theory of Governance. Oxford: Oxford University Press.

Hooghe, Liesbet, Tobias Lenz, and Gary Marks. 2019. "Contested World Order: The Delegitimation of International Governance." Review of International Organizations 14: 731-43.

Hurd, Ian. 2007. After Anarchy: Legitimacy and Power in the United Nations Security Council. Princeton, NJ: Princeton University Press.

Kelley, Judith, and Beth A. Simmons. 2015. "Politics by Number: Indicators as Social Pressure in International Relations." American Journal of Political Science 59 (1): 55-70.

Kelley, Judith, and Beth A. Simmons. 2020. "Governance by Other Means: Rankings as Regulatory Systems." International Theory 13 (1): 169-78.

Keohane, Robert O. 1984. After Hegemony: Cooperation and Discord in the World Political Economy. Princeton: Princeton University Press.

Keohane, Robert O. 2006. "The Contingent Legitimacy of Multilateralism." In Multilateralism under Challenge? Power, Institutional Order, and Structural Change, edited by Edward Newman, Ramesh Thakur, and John Tirman, 56-76. Tokyo: United Nations University Press.

Keohane, Robert O. 2020. "The Global Politics Paradigm: Guide to the Future or Only the Recent Past?" International Theory 13 (1): 112-21.

Koremenos, Barbara. 2016. The Continent of International Law: Explaining Agreement Design. Cambridge: Cambridge University Press.

Koremenos, Barbara, Duncan Snidal, and Charles Lipson. 2001. "The Rational Design of International Institutions." International Organization 55 (4): 761-99.

Krebs, Ronald R. 2015. Narrative and the Making of US National Security. Cambridge: Cambridge University Press 2015.

Krisch, Nico. 2017. "Liquid Authority in Global Governance." International Theory 9 (2): 237-60.

Lake, David A. 2010. "Rightful Rules: Authority, Order, and the Foundations of Global Governance." International Studies Quarterly 54 (3): 587-613.

Leander, Anna. 2005. "The Power to Construct International Security: On the Significance of Private Military Companies." Millennium: Journal of International Studies 33 (3): 803-26.

Leander Anna. 2020. "Locating (New) Materialist Characters and Processes in Global Governance." International Theory 13 (1): 157-68.

Lindberg, Leon N., and Stuart A. Scheingold. 1970. Europe's Would-Be Polity. Patterns of Change in the European Community. Englewood Cliffs, NJ: Prentice Hall.

Morse, Julia C., and Robert O. Keohane. 2014. "Contested Multilateralism." Review of International Organization 9 (1): 385-412.

O'Brien, Robert, Anne Marie Goetz, Jan Aart Scholte, and Marc Williams. 2000. Contesting Global Governance: Multilateral Economic Institutions and Global Social Movements. Cambridge: Cambridge University Press.

Pouliot, Vincent. 2016. International Pecking Orders: The Politics and Practice of Multilateral Diplomacy. New York: Cambridge University Press.

Pouliot, Vincent. 2020. "Global Governance in the Age of Epistemic Authority," International Theory 13 (1): 144-56.

Reus-Smit, Christian. 2007. "International Crises of Legitimacy." International Politics 44 (2): 157-74.

Rixen, Thomas, Lora Viola, and Michael Zürn, eds. 2016. Historical Institutionalism and International Relations: Explaining Institutional Development in the World. Oxford: Oxford University Press.

Scholte, Jan Aart, ed. 2011. Building Global Democracy: Civil Society and Accountable Global Governance. Cambridge and New York: Cambridge University Press.

Scholte, Jan Aart. 2020. "Beyond Institutionalism: Toward a Transformed Global Governance Theory." International Theory 13 (1): 179-91.

Steffek, Jens. 2003. "The Legitimation of International Governance: A Discourse Approach.” European Journal of International Relations 9 (2): 249-75.

Tallberg, Jonas, Karin Bäckstrand, and Jan Aart Scholte. 2018. Legitimacy in Global Governance: Sources, Processes, and Consequences. Oxford: Oxford University Press. 
Tallberg, Jonas, and Michael Zürn. 2019. "The Legitimacy and Legitimation of International Organizations: Introduction and Framework." Review of International Organizations 14 (4): 581-606.

Weber, Max. 1922/1978. Economy and Society. Berkeley, CA: University of California Press.

Wendt, Alexander. 1992. "Anarchy is What States Make of It: The Social Construction of Power Politics." International Organization 46 (2): 391-425.

Young, Kevin L. 2012. "Transnational Regulatory Capture? An Empirical Examination of the Transnational Lobbying of the Basel Committee on Banking Supervision." Review of International Political Economy 19 (4): 663-88.

Zaum, Dominik, ed. 2013. Legitimating International Organizations. Oxford: Oxford University Press.

Zürn, Michael. 2018. A Theory of Global Governance: Authority, Legitimacy, and Contestation. Oxford: Oxford University Press.

Zürn, Michael, Martin Binder, and Matthias Ecker-Ehrhardt. 2012. "International Authority and Its Politicization." International Theory 4 (1): 69-106.

Cite this article: Fioretos, O., Tallberg, J. 2021. "Politics and theory of global governance." International Theory 13, 99-111, doi:10.1017/S1752971920000408 